April 1995

\title{
The Hartford Steam Boiler Inspection and Insurance Company
}

Peter Moon

Follow this and additional works at: https://jdc.jefferson.edu/scitechnews

\section{Let us know how access to this document benefits you}

\section{Recommended Citation}

Moon, Peter (1995) "The Hartford Steam Boiler Inspection and Insurance Company," Sci-Tech News: Vol. 49 : Iss. 2 , Article 4.

Available at: https://jdc.jefferson.edu/scitechnews/vol49/iss2/4

This Article is brought to you for free and open access by the Jefferson Digital Commons. The Jefferson Digital Commons is a service of Thomas Jefferson University's Center for Teaching and Learning (CTL). The Commons is a showcase for Jefferson books and journals, peer-reviewed scholarly publications, unique historical collections from the University archives, and teaching tools. The Jefferson Digital Commons allows researchers and interested readers anywhere in the world to learn about and keep up to date with Jefferson scholarship. This article has been accepted for inclusion in Sci-Tech News by an authorized administrator of the Jefferson Digital Commons. For more information, please contact: JeffersonDigitalCommons@jefferson.edu. 


\section{THE HARTFORD STEAM BOILER INSPECTION AND INSURANCE COMPANY By Peter Moon}

Wow--that is a long company name, but very descriptive. Commonly referred to as HSB, this company got its start at the close of the Civil War, 1866, with the explosion of the boiler aboard The Sultana Riverboat coming up the Mississippi with Union troops. Most of the 1200 union troops died unnecessarily as a result of that accident. A group of men in the Hartford, Connecticut, area got together to form the Polytechnic Club. It quickly incorporated and changed its name.

The name reflected its headquarters location; steam boilers, since they were considered a primary symbol of the new industrial age; and examining exploded pieces to determine why the accident occurred. The company also worked with manufacturers to avoid future accidents, and HSB inspected operating pressure vessels and insured them for their structural integrity and lifetime expectancy. As a consequence, pressure vessel explosion and failure were no longer a way of life and expected to occur. The frequency of explosions and failures was once every four days! Today, HSB offers engineering services and property insurance that help protect people, property, and the environment worldwide. The company's core business is equipment breakdown and property insurance for commercial and industrial facilities.

The Technical Resource Center, a sixyear-old information center for HSB with
Peter Moon as its solo librarian, organizes and retrieves material in a more timely manner than previously accomplished. This state of the art center uses the Internet and multiple CD-Rom commercial products in concert with its online card catalog to exercise both print and electronic full-text or full-image documents. Although the emphasis is on current "clinical" material such as serials and newsletters sources, there is also an archival collection for HSB published documents and the ASME Boiler and Pressure Vessel Code back to the 1920s. This Code was adopted by ASME from the Hartford Standard, created by HSB.

Although the name implies an emphasis on technical information sources, the scope also includes insurance-related material, computer-technology information science source materials, as well as a good dose of business-related information. The audience served, although also heavily focused on the engineering community, which constitutes half of the company's 1,600 staff, also supports the information needs of such departments as Personnel, Administration, Finance, and the Information Systems Group, to mention just a few. The breadth is also considerable, reaching our newest subsidiary, HSB Engineering Insurance LTD, based in London, as well as such other subsidiaries as the Boiler Inspection and Insurance Company of Canada, HSB Reliability 
Technologies, HSB Professional Loss Control, and Radian Corporation, in addition to numerous branch office locations.

Often research questions can lead to locating information on a specific company, but we also can dig up the most unusual technical detail on specific manufactured products such as funeral home equipment to computer-related equipment--and let's not forget that boiler in the neighborhood church or the one to keep the bowling alley warm in the winter months!
As the incoming Chair for the Engineering Division of SLA, among my other duties is the planning for the Annual Conference in June 1996 in Boston. If you have ideas or questions about what Engineering is planning, or questions about HSB services or the TRC, I can be contacted at (203) 722-5486 or FAX (203) 722-5530, or on the Internet (pmoon@hsb.com).

Peter Moon is located at Hartford Steam Boiler Inspection \& Insurance Company, One State Street 8th Floor, Hartford, CT 06102

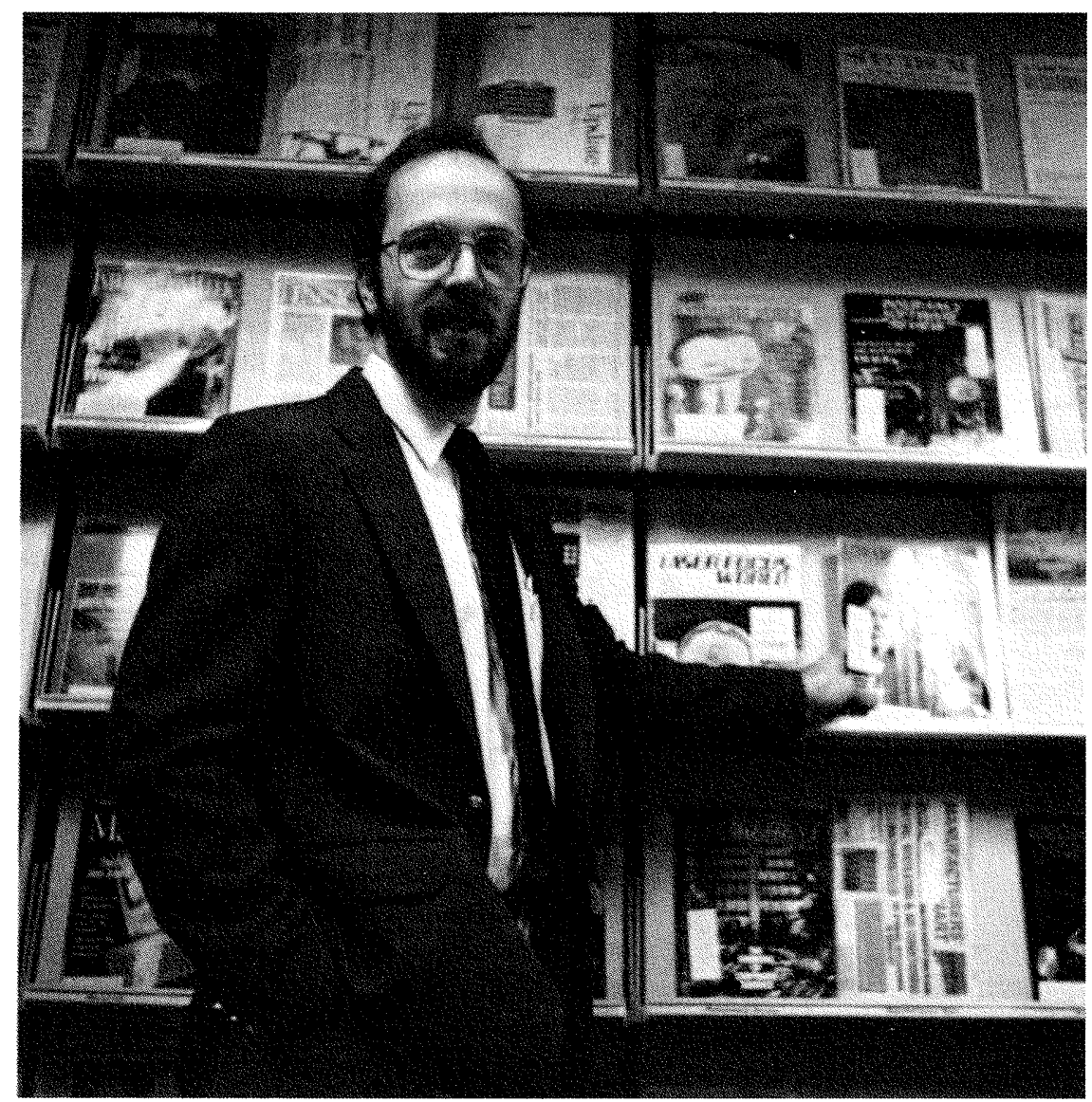

Peter Moon, Manager of HSB's Technical Resource Center, is exploring many avenues for expanding TRC's services - both in the number of employees served and the scope of services provided. 